\title{
Evaluation of seven mulch treatments for erosion control and vegetation establishment on steep slopes
}

\author{
G. Lee, R.A. McLaughlin, K.D. Whitely, and V.K. Brown
}

\begin{abstract}
Soil erosion and sediment pollution in and around construction sites can result from land disturbing activities that leave areas of unprotected soil during construction. This study evaluated different types of hydromulch for erosion control and grass establishment in comparison to straw alone or straw plus an application of polyacrylamide (PAM) on steep slopes at five construction sites in North Carolina. One site was located in the Coastal Plain (CP) region, and another in the Mountain (M) region, with the remaining three in the Piedmont (P1 through P3). At each site, 20 plots $(3 \mathrm{~m}$ [10 ft] wide by 6 to $9 \mathrm{~m}$ [20 to $30 \mathrm{ft}$ ] long) were established on a contiguous area. After applying grass seed, the erosion control treatments were as follows: wheat straw (Triticum aestivum) and wheat straw $+22.4 \mathrm{~kg} \mathrm{ha}^{-1}(20$ $\mathrm{lb} \mathrm{ac}{ }^{-1}$ ) of granular, linear, anionic PAM on all five sites; and hydromulches including flexible growth medium (FGM), stabilized mulch matrix (SMM), bonded fiber matrix (BFM), wood fiber/cellulosic blend (WCB), and wood fiber mulch (WFM) applied at three sites each. Runoff volumes, turbidity, eroded sediment, and nutrient concentration data were collected after natural rain events; grass growth and cover were also evaluated. At both the CP and M sites, there were no differences between treatments, most likely due to the sandy soil texture at $\mathrm{CP}$ and a combination of sandy soil texture and relatively light rainfall events at M. At P1, there was a trend of straw cover producing higher runoff volume, turbidity, total suspended solids (TSS), and in general higher concentrations and amount of nutrient loss compared to all hydromulch treatments. In contrast, at P2 and P3, hydromulches tended to have greater runoff volumes, turbidity, and TSS compared to straw. Also, on these sites, straw + PAM treatment had lower concentrations of total phosphorus (P) in runoff compared to WCB. The addition of PAM did not have an effect on runoff volumes at any site, but it reduced average turbidity on P2. Overall, there was no clear pattern of hydromulch advantages over straw as a mulch for reducing erosion or establishing grass on steep slopes.
\end{abstract}

Key words: erosion-hydromulch—polyacrylamide—-turbidity

Recent surveys of streams and rivers in the United States have ranked sediment as the second leading cause of impairment behind pathogens (USEPA 2012a). More than $45 \%$ of evaluated streams in the United States are in poor to fair condition due to excess streambed sediment (USEPA 2016). While there are many sources of sediment in streams, such as eroding stream banks and agriculture, runoff from construction sites can carry sediment loads 10 to 20 times those from agriculture and 1,000 to 2,000 times forest loading (USEPA 2005). The US Environmental Protection Agency (USEPA 2012b) now requires that bare soil on con- construction site conditions (e.g., subsoil materials, steep slopes, and no irrigation). Straw is one of the most common materials used for this type of mulching as it is often the least expensive and widely available in many areas. Mannering and Meyer (1963) found that higher application rates of straw (2.2, 4.4, and $9 \mathrm{Mg} \mathrm{ha}^{-1}\left[1,2\right.$, and $\left.\left.4 \mathrm{tn} \mathrm{ac}^{-1}\right]\right)$ maintained high infiltration rates and no erosion while low application rates, 0.6 and $1.1 \mathrm{Mg} \mathrm{ha}^{-1}\left(0.25\right.$ and $\left.0.5 \mathrm{tn} \mathrm{ac}^{-1}\right)$, resulted in soil loss of 6.7 and $2.2 \mathrm{Mg} \mathrm{ha}^{-1}$ (3 and 1 tn $\mathrm{ac}^{-1}$ ) on a $5 \%$ slope, respectively. They also found that erosion in any straw mulch cover was roughly $10 \%$ of the bare soil. Lemly (1982) compared five treatment methods used to stabilize seeded areas at urban and highway construction sites: asphalt-tacked straw, jute netting, mulch blanket, wood chips, and excelsior blanket. Reductions in the total sediment concentration in runoff ranged from 28\% (asphalt-tacked straw, $50 \%$ slope) to $90 \%$ (multiple treatments, $40 \%$ slope). Hydromulches, fiber materials mixed in water and sprayed on the soil, are another option for erosion control. Holt et al. (2005) found that a cotton (Gossypium hirsutum)-based hydromulch performed similar to or better than conventional wood and paper hydromulches in reducing soil loss. Before vegetation became established, erosion from bonded fiber matrix (BFM) hydromulch was roughly $10 \%$ of that from straw mulch (Benik et al. 2003b). However, after one growing season the BFM significantly reduced vegetation biomass compared to either bare soil or straw cover. These studies suggest there is a need for more research to help provide better guidance on the best mulch to use to both reduce erosion and establish vegetation.

In addition to mulches, the synthetic polymer polyacrylamide (PAM) has been used in a variety of ways to reduce erosion in furrow irrigation and on slopes (Sojka et al. 2007). PAM is a class of polymers with a wide range of properties, but those used for erosion control typically are long-chain (12 to $15 \mathrm{Mg} \mathrm{mol}^{-1}$ ), water-soluble molecules with a net anionic charge, which have been found to stabilize soil and flocculate sediment (Sojka et al. 2007). Mostaghimi et al.

Gina Lee, Kim D. Whitely, and Virginia K. Brown are former graduate research assistants and Rich A. McLaughlin is a professor in the Department of Soil Science, North Carolina State University, Raleigh, North Carolina. 
(1994) investigated the effectiveness of straw mulch, paper-based hydromulch, and two commercial synthetic polymers including PAM in reducing runoff, sediment, nitrogen $(\mathrm{N})$, and phosphorus (P) losses. They found that neither polymer alone was as effective as straw or hydromulch in reducing runoff and erosion. Straw mulch was the most effective in reducing runoff and losses of sediment, $\mathrm{N}$, and $\mathrm{P}$ until vegetation was established. Hayes et al. (2005) also found that PAM alone was not effective for erosion control on steep (50\%) slopes, although they indicated the tested rates of $11.2 \mathrm{~kg} \mathrm{ha}^{-1}\left(10 \mathrm{lb} \mathrm{ac}^{-1}\right)$ or less were likely too low to have effects. Straw significantly reduced erosion by more than an order of magnitude, but the addition of PAM did not have any effect at these rates. Both studies illustrated that PAM alone may not be effective for erosion control at low rates.

However, tests of higher rates of PAM on bare soil have suggested it may reduce erosion. Polyacrylamide (20 to $40 \mathrm{~kg} \mathrm{ha}^{-1}$ [18 to $\left.36 \mathrm{lb} \mathrm{ac}^{-1}\right]$ ) and gypsum (5 $\mathrm{Mg} \mathrm{ha}^{-1}[2.2$ tn $\left.\mathrm{ac}^{-1}\right]$ ), alone or in combination, generally decreased erosion and runoff in test beds under a rainfall simulator (Lee et al. 2010). Total soil loss for plots treated with PAM (80 $\left.\mathrm{kg} \mathrm{ha}^{-1}\left[71 \mathrm{lb} \mathrm{ac}^{-1}\right]\right)$ was reduced in the range of $40 \%$ to $54 \%$, compared to the untreated control (Flanagan et al. 2002a, 2002b). They also found that PAM and PAM with gypsum increased grass establishment and growth on treated plots compared to the control. Babcock and McLaughlin (2011) found that applying PAM (37 kg ha' ${ }^{-1}$ [33 $\left.\mathrm{lb} \mathrm{ac}^{-1}\right]$ ) with straw reduced mean runoff turbidity at three of four steep construction site slopes compared to straw. Different rates of PAM (25, 50 , and $75 \mathrm{~kg} \mathrm{ha}^{-1}\left[22,44\right.$, and $\left.66 \mathrm{lb} \mathrm{ac}^{-1}\right]$ ) and gypsum $\left(10,20\right.$, and $30 \mathrm{Mg} \mathrm{ha}^{-1}$ [4.5, 9 , and $\left.13.5 \mathrm{tn} \mathrm{ac}^{-1}\right]$ ) on a steep slope $(30 \%)$ did not reduce runoff volume but did reduce erosion compared with the control under intense $\left(75 \mathrm{~mm} \mathrm{~h}^{-1}\left[3 \mathrm{in} \mathrm{hr}^{-1}\right]\right)$ simulated rain (Akbarzadeh et al. 2009). These studies suggest that PAM may be effective at reducing erosion at higher rates and in combination with a mulch.

Since there is little information on the performance of different hydromulches on steep slopes for both erosion control and establishing vegetation, we initiated a multisite study on five different construction site slopes. Since straw is a common mulch used construction sites and it costs much less than hydromulch, we used that as a "control" to compare to hydromulch. Furthermore, with evidence that PAM applied with a mulch can enhance its erosion control (Babcock and McLaughlin 2011; Soupir et al. 2004; RoaEspinosa 1999), we included that system to determine if it was an effective option for contractors. The objective of this study was to evaluate different types of hydromulch for erosion control and vegetation establishment on steep slopes in comparison to straw alone and straw with a PAM application under a wide variety of conditions. The ground covers were tested in plots established within sites that were prepared by commercial contractors under the supervision of North Carolina Department of Transportation (NCDOT) staff, with the intention of determining their differences under "real" conditions.

\section{Materials and Methods}

Description of Study Sites. This study was conducted on five road construction sites, all of which were located in relatively rural areas (figure 1 and table 1). For logistical reasons, each site was studied sequentially, so data were collected one site at a time. The first site (CP) was located in the coastal region near Kinston, North Carolina, and was a 3:1 fill slope. The second site (M) was located in the mountain region near West Jefferson, North Carolina, and was a 2:1 cut slope (50\% slope). The remaining three sites were all located in the Piedmont region, near Raleigh, North Carolina. The third site (P1) was a 2:1 fill slope located near Garner, North Carolina. The fourth site (P2) was a 2:1 cut slope in Apex, North Carolina. The fifth site (P3) was a 2:1 fill slope in Holly Springs, North Carolina. Soil characteristics are provided in table 1 , and in most cases the surface material was a subsoil after cut and fill operations reached final grade. The $\mathrm{CP}$ site was a stockpile of surface soil material that was later redistributed on the graded areas.

Plot Setup. Each site was prepared by the site contractors according to specifications of the NCDOT, as described herein. Slopes were graded to a 2:1 (3:1 at $\mathrm{CP}$ ) slope and tracked up and down slope by a bulldozer. The sites selected were limed, fertilized, and seeded following NCDOT specifications (table 2). Wheat (Triticum aestivum) straw was applied by hand, except at P2 where a straw blower was used, and sprayed with an asphalt tackifier.

The selected area at each site was divided into 20 plots, which were $3 \mathrm{~m}$ wide by 9 $\mathrm{m}$ long, except plots at P1, which were $6 \mathrm{~m}$ long due to a shorter slope. Each site had five mulch treatments replicated on four plots each, arranged in a randomized, complete block design. After seed, fertilizer, and lime application, treatments were applied according to the manufacturer's (hydromulch) or NCDOT specifications in a randomized, complete block design. All sites included both $3,000 \mathrm{~kg} \mathrm{ha}^{-1}\left(2,680 \mathrm{lb} \mathrm{ac}^{-1}\right)$ wheat straw + tackifier (straw) and $3,000 \mathrm{~kg}$ $\mathrm{ha}^{-1}$ wheat straw + tackifier with $22.4 \mathrm{~kg}$ $\mathrm{ha}^{-1}\left(20 \mathrm{lb} \mathrm{ac}^{-1}\right)$ of granular, linear, anionic PAM (straw + PAM) (APS 705, Applied Polymer Systems, Woodstock, Georgia). Hydromulches used in the study (table 3) included flexible growth medium (FGM), stabilized mulch matrix (SMM), BFM, wood fiber/cellulosic blend (WCB), and wood fiber mulch (WFM). All hydromulches were from Profile Inc., Chicago, Illinois, with the exception of Soil Guard BFM (Mat Inc., Floodwood, Minnesota). Each was applied at three of the five sites as indicated in table 4. Hydromulches were selected based on the test results from a previous study (Whitley 2011), in which several of the lower-cost, paper-based hydromulches were found to provide poor coverage and grass germination in soil boxes placed on a slope.

Biomass and Vegetative Cover. Aboveground grass biomass and cover were evaluated after a period of time sufficient for the grass to reach a height of at least 10 to $12 \mathrm{~cm}$ (4 to 5 in) (table 1 ). Biomass was determined using a square grid, 1 by $1 \mathrm{~m}$ (3.3 by $3.3 \mathrm{ft}$ ), divided into 25 squares of 20 by $20 \mathrm{~cm}$ ( 8 by 8 in). The grid was placed onto each plot near the top, in the middle, and toward the bottom. Each time, three randomly selected squares were clipped at each sample location, for a total sample of nine squares per plot. The samples were combined, oven-dried overnight at $60^{\circ} \mathrm{C}$ $\left(140^{\circ} \mathrm{F}\right)$, and weighed to estimate biomass for the total plot area.

Vegetative cover on $\mathrm{CP}, \mathrm{M}$, and $\mathrm{P} 2$ was assessed by independent visual estimation from four observers who estimated the amount of cover (\%) on each plot. The independent estimates were averaged to obtain a single cover estimate for each plot. On P1 and $\mathrm{P} 3$, sufficient digital photos were available so vegetation analysis was performed using geographic information system (GIS) software (ArcGIS v. 10.1, 2012, ESRI, Redlands, California). In addition, to help explain differences found at the Piedmont sites, straw 
Table 1

Summary of site characteristics for the Coastal Plain (Kinston; CP), Mountain (West Jefferson; M), and three Piedmont (Raleigh area; P1 to P3) locations.

\begin{tabular}{|c|c|c|c|c|c|c|c|c|c|}
\hline Site & Location & Date seeded & $\begin{array}{l}\text { Time to } \\
\text { vegetation } \\
\text { evaluation (d) }\end{array}$ & $\begin{array}{l}\text { Total } \\
\text { precipitation } \\
(\mathrm{mm}) / \text { events/ } \\
\text { sample } \\
\text { collections }\end{array}$ & Slope type & $\begin{array}{l}\text { Bulk } \\
\text { density } \\
\left(\mathrm{g} \mathrm{cm}^{-3} \text { ), }\right. \\
0 \text { to } 7.5 \mathrm{~cm}\end{array}$ & $\begin{array}{l}\text { Sand } \\
\text { (\%) }\end{array}$ & $\begin{array}{l}\text { Silt } \\
\text { (\%) }\end{array}$ & $\begin{array}{l}\text { Clay } \\
\text { (\%) }\end{array}$ \\
\hline $\mathrm{CP}$ & $35.266116,-77.682367$ & Nov. 3, 2009 & 75 & $287 / 11 / 5$ & $3: 1$, fill & 1.52 & 80 & 14 & 6 \\
\hline M & $36.334739,-81.424830$ & Sept. 1, 2010 & 62 & $121 / 12 / 3$ & $2: 1$, cut & 1.36 & 72 & 23 & 7 \\
\hline P1 & $35.686250,-78.598383$ & May 10, 2011 & 90 & $253 / 8 / 8$ & $2: 1$, fill & 1.57 & 74 & 13 & 13 \\
\hline P3 & $35.685640,-78.669811$ & June 21, 2012 & 55 & $172 / 5 / 3$ & $2: 1$, fill & 1.52 & 55 & 29 & 16 \\
\hline
\end{tabular}

cover was also estimated for P1, P2, and P3 using the same method since good photos were available at plot establishment. Every photo was separated into two groups of digital pixels based on color, and the grass and straw cover were estimated from the resulting pixel counts.

Water Quality. On each plot, two 1.2 $\mathrm{m}(4 \mathrm{ft})$ pieces of $10 \mathrm{~cm}$ (4 in) edging were inserted into the soil to $5 \mathrm{~cm}$ (2 in) in the plot center in a "V" formation to direct water flow into a $10 \mathrm{~cm}$ diameter pipe (figure 2). At $C P$ and $M$, runoff from the pipes was first collected in $38 \mathrm{~L}(10 \mathrm{gal})$ containers. Excess water from the $38 \mathrm{~L}$ containers flowed by gravity (M) or was pumped using $12 \mathrm{~V}$ bilge pumps into a hose leading to 380 L (100 gal) tubs. Flow was divided with half going into the containers and the other half flowing onto the ground in order to prevent overflow in the large tubs during heavy runoff events, so the volumes in the large tubs were doubled when calculating runoff. The idea behind this set up was that the majority of the sediment would settle in the first container and excess, turbid water would accumulate in the large tanks. Sediment from the container was deposited into the larger tanks and mixed prior to collecting samples for analysis. On the P1 through P3 sites, runoff from the pipes flowed into $38 \mathrm{~L}$ tubs that were placed inside the 380 $\mathrm{L}$ tanks. When there was no overflow from the tub into the tanks, samples were taken from the tubs. When there was overflow from the tubs, they were emptied into the tanks and mixed before samples were taken. Both the $38 \mathrm{~L}$ tubs and the $380 \mathrm{~L}$ tanks were calibrated so water depth could be converted to runoff volume. Calibration was performed by adding a known volume of water to the container or tank and recording the depth, then developing a linear regression equation to calculate volume from depth.

\section{Figure 1}

Map of the five locations of plot installations in North Carolina in the Coastal Plain (CP), Mountain $(M)$, and Piedmont $\left(\mathrm{P}_{1}\right.$ through $\left.\mathrm{P}_{3}\right)$ regions.

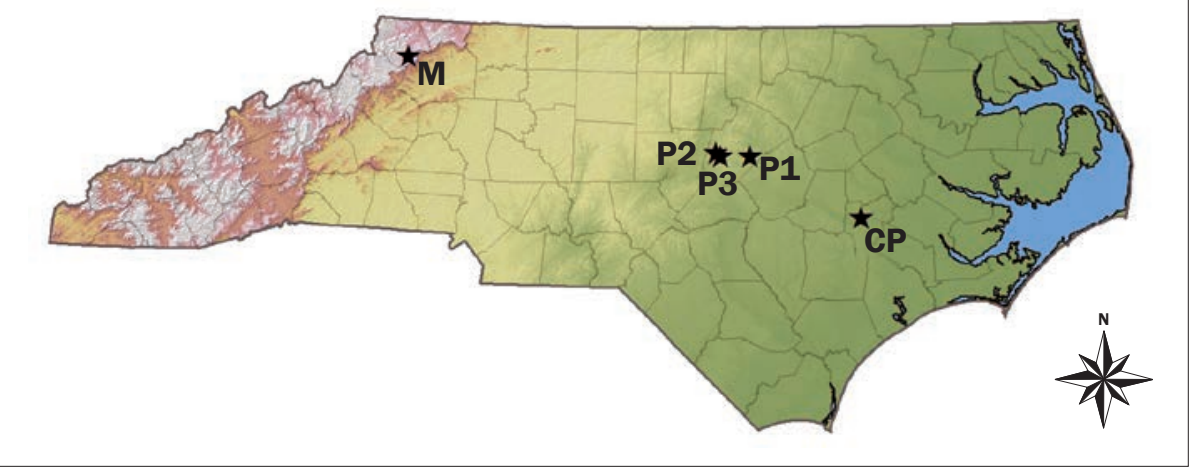

Table 2

Grass seed (CP and $\mathrm{P}_{1}$ through $\mathrm{P}_{3}$ sites), fertilizer, and lime specified for application at all sites.

\begin{tabular}{|c|c|}
\hline Addition & Rate (kg ha-1) \\
\hline Tall fescue & $56 / 84 *$ \\
\hline Centipede grass & 11 \\
\hline Bermudagrass & 28 \\
\hline Kentucky bluegrass & $22 *$ \\
\hline Rye grain & $28 *$ \\
\hline Fertilizer & 560 (10:20:20 nitrogen:phosphorus:potassium) \\
\hline Limestone & 4,480 (ground dolomitic) \\
\hline
\end{tabular}

* Grass seed rates for M; no centipede or Bermudagrass were applied.

Turbidity was measured using an ANALITE NEP-160 portable turbidity meter (McVan Instruments, Melbourne, Australia). Measured turbidities were corrected with a standard curve based on formazine standards. Total suspended solids (TSS) was determined by filtration following the standard methods for the examination of water and wastewater (Clesceri et al. 1998). Total sediment eroded (TSE) was calculated from runoff volume and TSS. Nutrient anal- ysis was performed on runoff samples from P1 through P3 for the first five rain events. The analyses included $\mathrm{N}$ (ammonium $\left[\mathrm{NH}_{4}\right]$, nitrate $\left[\mathrm{NO}_{3}\right]$, and total Kjeldahl nitrogen $[\mathrm{TKN}]), \mathrm{P}$ (phosphate $\left[\mathrm{PO}_{4}\right]$ and total $\mathrm{P}[\mathrm{TP}])$, and total organic carbon (TOC) (Greenberg et al. 2005).

Sites $\mathrm{CP}$ and $\mathrm{M}$ were several hours from campus, and as result, some samples included more than one event. The runoff volume was calculated as a fraction of the total rainfall 


\section{Table 3}

Hydromulch products and application rates used in the study. The Soil Guard bonded fiber matrix (BFM) was only used at the Coastal Plain site.

\begin{tabular}{llll}
\hline Symbol & Type & Product & Rate (kg ha-1) \\
\hline FGM & Flexible growth medium & Flexterra & 3,900 \\
SMM & Stabilized mulch matrix & Terra-Matrix & 3,900 \\
BFM & Bonded fiber matrix & Soil Guard, Hydroblanket & 3,900 \\
WCB & Wood-cellulosic blend (70:30) & Enviroblend & 2,800 \\
WFM & Wood fiber & Conwed Fibers 1000 & 2,240 \\
\end{tabular}

\section{Table 4}

Summary of treatments at each site.

\begin{tabular}{llllllll}
\hline Site & Straw & Straw + PAM & FGM & SMM & BFM & WFM & WCB \\
\hline CP & $\mathrm{x}$ & $\mathrm{x}$ & - & - & $\mathrm{x}$ & $\mathrm{x}$ & $\mathrm{x}$ \\
M & $\mathrm{x}$ & $\mathrm{x}$ & $\mathrm{x}$ & $\mathrm{x}$ & $\mathrm{x}$ & - & - \\
P1 & $\mathrm{x}$ & $\mathrm{x}$ & $\mathrm{x}$ & $\mathrm{x}$ & $\mathrm{x}$ & - & - \\
P2 & $\mathrm{x}$ & $\mathrm{x}$ & $\mathrm{x}$ & - & - & $\mathrm{x}$ & $\mathrm{x}$ \\
P3 & $\mathrm{x}$ & $\mathrm{x}$ & - & $\mathrm{x}$ & - & $\mathrm{x}$ & $\mathrm{x}$ \\
\hline
\end{tabular}

Notes: $\mathrm{CP}=$ Coastal Plain region. $\mathrm{M}=$ Mountain region. $\mathrm{P} 1$ to $\mathrm{P} 3=$ Piedmont region. $\mathrm{x}=$ treatment present. $-=$ treatment absent. $\mathrm{PAM}=$ Polyacrylamide. $\mathrm{FGM}=$ flexible growth media. SMM = stabilized mulch matrix. BFM = bonded fiber matrix. WFM = wood fiber mulch. WCB $=70: 30$ wood fiber/cellulose blend.

over the monitored period. Site P3 had runoff volumes greater than the tank capacity for the fourth and fifth storms; only turbidity and TSS from these storms were included in the averages.

Bulk Density and Soil Texture. At each site, 20 soil samples were taken from the surface using a soil corer $(7.6 \mathrm{~cm}$ [3 in] deep, $5.1 \mathrm{~cm}$ [2 in] diameter) in alternating locations from the bottom to the top of the plots. Each sample was used to determine bulk density (Dane et al. 2004) and subsequently particle size by the hydrometer method (Gee and Or 2002).

\section{Figure 2}

Example of plot set up at (a) Coastal Plain (CP), (b) Mountain (M), and (c) Piedmont ( $\left.\mathrm{P}_{1}\right)$ showing the edging and the pipe carrying the runoff to the collection tubs in different arrangements. Note that the CP photo was taken during sample collection, so the small tubs, removed to collect sediment, had not been placed back under the runoff pipe.

(a)

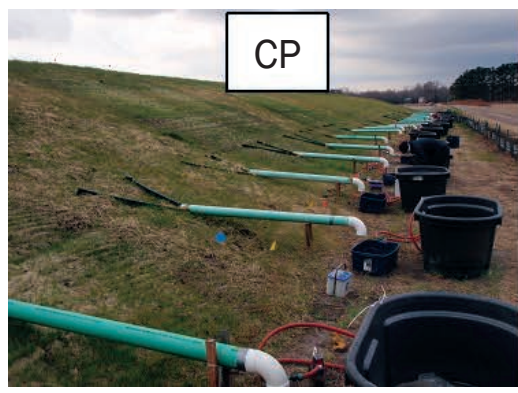

Data Analysis. The data from each site were analyzed separately to determine treatment effects. All data were analyzed using SAS software and the GLM procedure (SAS version 9.2, 2008, SAS Institute, Cary, North Carolina). Data were log transformed to ensure normality and equality of variance. Analysis of variance was used to analyze treatment effects. Differences among treatments were evaluated $(p \leq 0.05)$ for biomass and cover percentage, average runoff, turbidity, TSS, TSE, and nutrients loss among treatments using Fisher's Least Significant Difference (LSD) for mean separation. No statistical comparisons were made between sites since there were substantial differences in conditions at each site over the three-year period of the study. However, site differences are discussed in an effort to discern patterns and factors influencing the results. Cost information was obtained from Sunbelt Rentals (Raleigh, North Carolina) for the water truck and from the North Carolina Department of Transportation website (https://connect.ncdot.gov/Pages/default. aspx; 2015 six-month averages) for seeding and mulching contractor bids.

\section{Results and Discussion}

Water Quantity and Quality. The rainfall totals and number of storms varied considerably for each site (table 1). Sites CP, P1, and P3 all had substantial amounts of precipitation during the study period (2.8 to $3.8 \mathrm{~mm}$ $\mathrm{d}^{-1}\left[0.11\right.$ to 0.15 in day $\left.\left.{ }^{-1}\right]\right)$, while $\mathrm{M}$ and $\mathrm{P} 2$ had lower amounts $\left(2\right.$ and $1.1 \mathrm{~mm} \mathrm{~d}^{-1}[0.08$ and 0.04 in day $\left.^{-1}\right]$, respectively). With typical monthly precipitation of 75 to $100 \mathrm{~mm}$ (2.95 to 3.94 in) (SCONC 2017), M and P2 had below average rainfall, and the remaining three normal amounts.

At CP, there were no differences in any water quantity or quality parameter measured, perhaps due to the sandy soil texture (table 5). At $M$, there were also no differences among treatments, perhaps due to a combination of high infiltration (soil averaged $72 \%$ sand) and relatively light rainfall events that occurred there. Expected rainfall for September to October, based on State Climate Office of North Carolina for the West Jefferson area, would be around $200 \mathrm{~mm}$ (7.9 in), and total rainfall during experiment was $121 \mathrm{~mm}(4.8$ in), with only one rain event that exceeded (b)

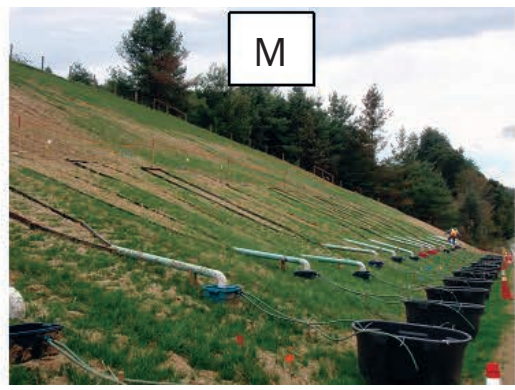

(c)

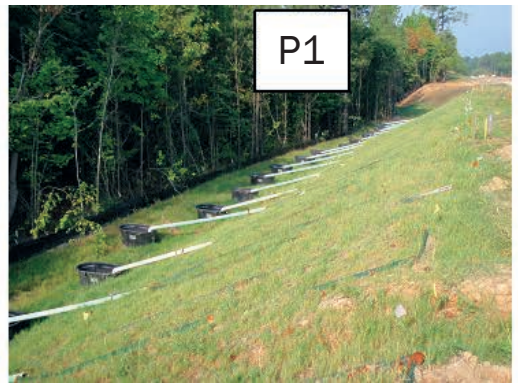


$10 \mathrm{~mm}$ (0.4 in). Overall, the runoff from $\mathrm{CP}$ and $\mathrm{M}$ contained much less sediment compared to the Piedmont sites. There was a trend of hydromulch covers producing lower runoff volume, turbidity, TSS, and TSE compared to the straw treatment at P1, with FGM cover runoff volumes lower by $100 \%$ and BFM and SMM lower by $60 \%$ compared to straw. Also, in general, hydromulch covers produced lower concentrations and amount of loss of nutrients in runoff compared to the straw and straw + PAM covers (table 6). Compared to straw, the FGM had significantly lower values for all water quality parameters measured except TOC at P1. At P1, the FGM treatment was superior to straw, and often to other treatments, for all water quality parameters. There were no differences among BFM, straw, and straw + PAM treatments for any water quality parameters at P1, similar to Babcock and McLaughlin (2011). There were three significant (24 to 37 $\mathrm{mm}$ [0.9 to $1.5 \mathrm{in}])$ rain events in the first 22 days at P1 and about half of the precipitation occurred over an eight-day period 70 days into the trial, which explains why it had the highest values for most parameters measured. Babcock and McLaughlin (2011) reported the first storm event $(2.6 \mathrm{~cm}[1.04$ in]) occurred about a week after the plots were installed and produced at least $50 \%$ of all sediment generated for all treatments.

In contrast, at P2 the straw and straw + PAM treatments generally had less runoff and better water quality than FGM, WFM, and WCB. The same trend of WFM and WCB having higher turbidity, TSS, and TSE compared to straw and straw + PAM was found on P3. This was probably caused largely by different application rates of straw on these sites. Based on the GIS analysis of photos taken at each site, at P1 straw cover appears to be about $75 \%$ while the cover on $\mathrm{P} 2$ and P3 was above 95\% (figure 3). Mannering and Meyer (1963) found that an application rate of wheat straw $\left(2.4 \mathrm{Mg} \mathrm{ha}^{-1}\left[1 \mathrm{tn} \mathrm{ac}^{-1}\right]\right)$, similar to our target rate, maintained high infiltration rates and resulted in no erosion, while application at lower rates resulted in considerable erosion.

The addition of PAM to the straw did not significantly affect runoff volumes on any of five sites. The straw + PAM treatment only had significantly lower turbidity compared to straw on P2, possibly due to less intense rainfall patterns or a soil that was more reactive to the PAM. The addition of

Table 5

Average total runoff volume, turbidity, total suspended sediment, and total sediment load at all five sites. Treatment averages with different letters are significantly different within each site at $\alpha=0.05$.

\begin{tabular}{|c|c|c|c|c|c|}
\hline \multirow[b]{2}{*}{ Treatment } & \multicolumn{5}{|c|}{ Site (number of events) } \\
\hline & CP (7) & M (12) & P1 (8) & P2 (9) & P3 (5) \\
\hline \multicolumn{6}{|c|}{ Total runoff volumes (\% of precipitation during monitoring period) } \\
\hline Straw & 12.0 & 1.6 & $26.4 a$ & $3.3 \mathrm{c}$ & $14.4 \mathrm{~b}$ \\
\hline Straw + PAM & 9.8 & 1.1 & $20.6 a b$ & $5.4 \mathrm{bc}$ & 18.1ab \\
\hline SMM & $\mathrm{N} / \mathrm{A}$ & 1.2 & $18.3 b c$ & N/A & $22.2 \mathrm{ab}$ \\
\hline BFM & 14.2 & 1.3 & $18.4 a b$ & N/A & N/A \\
\hline FGM & $\mathrm{N} / \mathrm{A}$ & 0.97 & $12.6 c$ & $8.2 a$ & N/A \\
\hline WFM & 9.6 & $\mathrm{~N} / \mathrm{A}$ & $\mathrm{N} / \mathrm{A}$ & $10.1 a$ & $26.5 a b$ \\
\hline WCB & 10.1 & $\mathrm{~N} / \mathrm{A}$ & $\mathrm{N} / \mathrm{A}$ & $9.4 a b$ & $29.3 a$ \\
\hline \multicolumn{6}{|c|}{ Average turbidity (NTU) } \\
\hline Straw & 39.6 & 44 & $1,274 a$ & $482 c$ & 631ab \\
\hline Straw + PAM & 23.1 & 43 & $1,174 a$ & $320 d$ & $585 b$ \\
\hline SMM & $\mathrm{N} / \mathrm{A}$ & 52 & $824 a$ & $\mathrm{~N} / \mathrm{A}$ & 1,833ab \\
\hline BFM & 48.6 & 57 & $987 a$ & $\mathrm{~N} / \mathrm{A}$ & $\mathrm{N} / \mathrm{A}$ \\
\hline FGM & $\mathrm{N} / \mathrm{A}$ & 52 & $420 b$ & $612 b$ & $\mathrm{~N} / \mathrm{A}$ \\
\hline WFM & 26.4 & N/A & N/A & $945 a b$ & $2,403 a$ \\
\hline WCB & 52.3 & $\mathrm{~N} / \mathrm{A}$ & $\mathrm{N} / \mathrm{A}$ & 1,040a & $2,373 a$ \\
\hline \multicolumn{6}{|c|}{ Average total suspended sediment ( $\left.\mathrm{mg} \mathrm{L}^{-1}\right)$} \\
\hline Straw & 142 & 355 & $3,472 a$ & $879 a b$ & $1,686 b$ \\
\hline Straw + PAM & 148 & 383 & $1,997 a$ & $646 b$ & $1,241 b$ \\
\hline SMM & $\mathrm{N} / \mathrm{A}$ & 350 & 1,937ab & $\mathrm{N} / \mathrm{A}$ & $2,584 b$ \\
\hline BFM & 135 & 325 & $2,773 a$ & $\mathrm{~N} / \mathrm{A}$ & N/A \\
\hline FGM & $\mathrm{N} / \mathrm{A}$ & 387 & $769 b$ & $1,182 a$ & N/A \\
\hline WFM & 178 & $\mathrm{~N} / \mathrm{A}$ & $\mathrm{N} / \mathrm{A}$ & $1,746 a$ & $4,527 a b$ \\
\hline WCB & 202 & $\mathrm{~N} / \mathrm{A}$ & $\mathrm{N} / \mathrm{A}$ & $1,885 a$ & 6,156a \\
\hline \multicolumn{6}{|c|}{ Total sediment eroded $\left(\mathrm{kg} \mathrm{ha}^{-1}\right)$} \\
\hline Straw & 7 & 14 & $1,278 a$ & $88 \mathrm{bc}$ & $65 b$ \\
\hline Straw + PAM & 4.5 & 10 & $345 a b$ & $137 c$ & $38 b$ \\
\hline SMM & N/A & 12 & $349 b c$ & N/A & $61 b$ \\
\hline BFM & 8 & 13 & $554 a b$ & N/A & N/A \\
\hline FGM & $\mathrm{N} / \mathrm{A}$ & 14 & $104 c$ & $195 a b$ & $\mathrm{~N} / \mathrm{A}$ \\
\hline WFM & 7.3 & N/A & N/A & $322 a$ & $151 a b$ \\
\hline WCB & 11.7 & $\mathrm{~N} / \mathrm{A}$ & $\mathrm{N} / \mathrm{A}$ & $513 a b$ & $246 a$ \\
\hline
\end{tabular}

PAM to straw did reduce TSS substantially on P1 through P3, although not different at $p=0.10$. Polyacrylamide has been found to preserve surface aggregate structure, prevent surface crusting, increase infiltration, and decrease runoff volume (Sojka et al. 2007; Green et al. 2000; Vacher et al. 2003; Yu et al. 2003; Flanagan et al. 2002a, $2002 b$ ). However, other studies reported that the addition of PAM to ground covers did not reduce runoff volume on steep slopes (McLaughlin and Brown 2006; Hayes et al. 2005). We also did not observe overall differences between straw treatment with and without PAM at any site. This may have been due to the dry-granular PAM washing off before it had a chance to dissolve and become activated. Traces of PAM granules were evident in runoff from the first and second storm events on P1. PAM in solution has been found to be more effective in controlling runoff and erosion than the dry granular application of PAM when applied with ground covers (Peterson et al. 2002; Babcock and McLaughlin 2013). PAM applied to the straw did not reduce turbidity on average at P1 and P3, while on P2 the addition of PAM did reduce turbidity, 


\section{Table 6}

Average nitrogen (ammonium [ $\left.\mathrm{NH}_{4}\right]$, nitrate [NO $]$, and total Kjehldahl nitrogen [TKN]), phosphorus (phosphate [PO ] and total P [TP]), and total organic carbon (TOC) concentrations and total losses in runoff at Piedmont region sites ( $P_{1}$ through $\left.P_{3}\right)$. Values represent the first five events for $P_{1}$ and $P_{2}$ and three events for $P_{3}$. Treatment averages with different letters are significantly different within each site at $\alpha=0.05$.

\begin{tabular}{|c|c|c|c|c|c|c|c|c|c|c|c|c|}
\hline Site/treatment & $\begin{array}{l}\mathrm{NH}_{4} \\
\left(\mathrm{mg} \mathrm{L}^{-1}\right)\end{array}$ & $\begin{array}{l}\mathrm{NH}_{4} \\
\left(\mathrm{~kg} \mathrm{ha}^{-1}\right)\end{array}$ & $\begin{array}{l}\mathrm{NO}_{3} \\
\left(\mathrm{mg} \mathrm{L}^{-1}\right)\end{array}$ & $\begin{array}{l}\mathrm{NO}_{3} \\
\left(\mathrm{~kg} \mathrm{ha}^{-1}\right)\end{array}$ & $\begin{array}{l}\text { TKN } \\
\left(\mathrm{mg} \mathrm{L}^{-1}\right)\end{array}$ & $\begin{array}{l}\text { TKN } \\
\left(k^{\prime} h^{-1}\right)\end{array}$ & $\begin{array}{l}\mathrm{PO}_{4} \\
\left(\mathrm{mg} \mathrm{L}^{-1}\right)\end{array}$ & $\begin{array}{l}\mathrm{PO}_{4} \\
\left(\mathrm{~kg} \mathrm{ha}^{-1}\right)\end{array}$ & $\begin{array}{l}\text { TP } \\
\left(\mathrm{mg} \mathrm{L}^{-1}\right)\end{array}$ & $\begin{array}{l}\begin{array}{l}\text { TP } \\
\left(\mathrm{kg} \mathrm{ha}^{-1}\right)\end{array} \\
\end{array}$ & $\begin{array}{l}\text { TOC } \\
\left(\mathrm{mg} \mathrm{L}^{-1}\right) \\
\end{array}$ & $\begin{array}{l}\text { TOC } \\
\left(\mathrm{kg} \mathrm{ha}^{-1}\right)\end{array}$ \\
\hline \multicolumn{13}{|l|}{ P1 } \\
\hline Straw & 3.3a & $1.77 a$ & $4.5 a$ & $3.04 a$ & $12.1 \mathrm{a}$ & $7.20 a$ & $0.36 a$ & 0.15 & $2.5 a$ & $1.55 a$ & 21.3ab & $10.06 a$ \\
\hline FGM & $1.4 \mathrm{c}$ & $0.64 b$ & $1.8 \mathrm{bc}$ & $0.78 b$ & $5.0 c$ & $1.90 \mathrm{c}$ & $0.14 c$ & 0.06 & $0.63 c$ & $0.25 c$ & $16.1 b$ & $5.77 b$ \\
\hline SMM & $2.1 \mathrm{~b}$ & $0.83 b$ & $3.6 a b$ & $1.08 \mathrm{~b}$ & $7.4 b$ & $3.20 b c$ & $0.22 a b c$ & 0.08 & $1.1 \mathrm{~b}$ & $0.53 b c$ & $22.5 a$ & $9.14 a$ \\
\hline Straw & 1.1 & 0.05 & $0.24 a b$ & $0.01 b$ & 2.9 & 0.14 & 0.16 & 0.007 & $0.61 a b$ & $0.029 a b$ & $8.53 b$ & $0.47 b$ \\
\hline Straw + PAM & 0.98 & 0.10 & $0.26 a b$ & $0.03 a b$ & 3.1 & 0.40 & 0.19 & 0.007 & $0.43 b$ & $0.045 b$ & $7.04 b$ & $0.65 b$ \\
\hline FGM & 1.0 & 0.16 & $0.2 b$ & $0.02 a b$ & 2.6 & 0.19 & 0.16 & 0.02 & $0.65 a b$ & $0.074 a b$ & $12.2 \mathrm{a}$ & 1.36ab \\
\hline WFM & 0.8 & 0.15 & $0.3 a b$ & $0.04 a b$ & 2.8 & 0.38 & 0.05 & 0.009 & $0.70 a b$ & $0.083 a$ & $12.1 a$ & $1.88 a$ \\
\hline WCB & 1.0 & 0.19 & $0.3 a$ & $0.05 a$ & 3.9 & 0.69 & 0.05 & 0.009 & $0.87 a$ & $0.134 a b$ & $9.0 \mathrm{~b}$ & 1.29ab \\
\hline SMM & 4.9 & 0.31 & 1.1 & 0.07 & 10.2 & 0.73 & 1.15 & 0.09 & $2.45 a b$ & $0.19 a b$ & 23.4 & 1.96 \\
\hline WFM & 4.3 & 0.37 & 1.5 & 0.13 & 10.1 & 0.87 & 0.46 & 0.03 & $1.89 a b$ & $0.13 a b$ & 18.2 & 1.97 \\
\hline WCB & 4.1 & 0.62 & 1.4 & 0.23 & 10.7 & 1.54 & 0.76 & 0.12 & $2.71 a$ & $0.36 a$ & 19.6 & 3.22 \\
\hline
\end{tabular}

Notes: $\mathrm{PAM}=$ polyacrylamide. FGM = flexible growth media. $\mathrm{SMM}=$ stabilized mulch matrix. BFM = bonded fiber matrix. WFM = wood fiber mulch. WCB $=70: 30$ wood fiber/cellulose blend.

\section{Figure 3}

Examples of straw cover at Piedmont ( $P_{1}$ through $P_{3}$ ) sites: (a) $P_{1}$ (low straw application), (b) $P_{2}$ (good straw application), and (c) P3 (overapplication of tackifier).

(a)

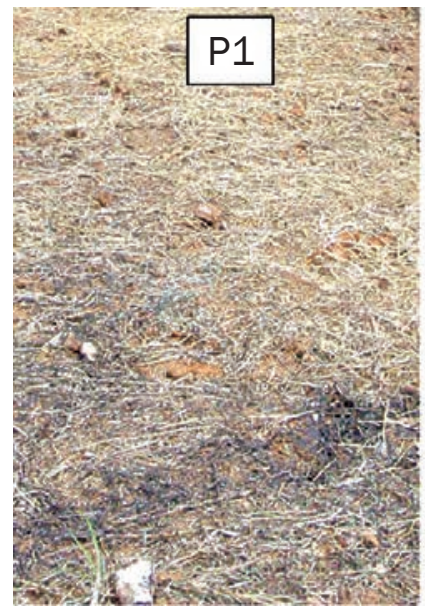

(b)

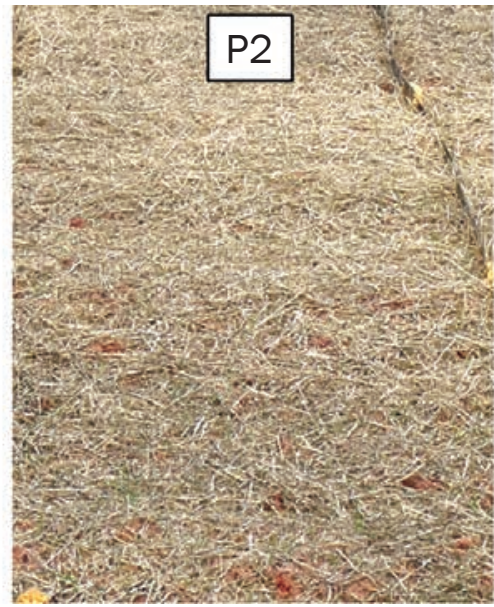

(c)

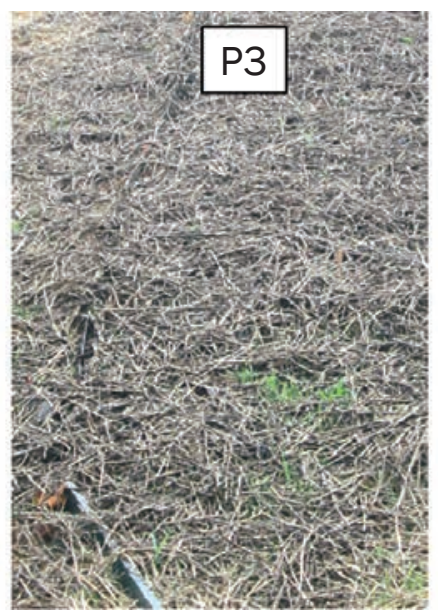

possibly due to the rainfall patterns. At P2, the rainfall totals were similar or less than P1 and P3 but spread over two to four times as many events, so the PAM may have remained active longer. Partington and Mehuys (2005) suggested that PAM provided no significant erosion control after a natural rainfall on a loam soil. On P3, the addition of PAM to straw was effective in turbidity reduction only during the first storm event but not the other four. McLaughlin and Brown (2006) had similar results, where the addition of PAM reduced turbidity during the first event but not for the following events, while
Babcock and McLaughlin (2011) found the effect lasted up to three events.

The FGM and SMM hydromulches resulted in lower turbidity than the more economical WFM and WCB at P2 and P3. At $\mathrm{P} 3$, the TSS and TSE were also lower in the SMM plots compared to WFM and WCB. 
These results suggest that the more expensive materials (FGM and SMM) may provide higher erosion protection and improve runoff water quality. However, at both sites the straw covers performed as well as the FGM and SMM covers. Only at P1 did the FGM hydromulch significantly reduce turbidity and sediment losses compared to straw, but the straw cover was much lower at that site. Overall, the runoff and sediment losses were similar to Benik et al. (2003a) for straw and erosion control blanket mulches and mostly lower than the Hayes et al. (2005) straw plots, both measured from natural rainfall events.

There were many differences in the concentration and amount of nutrient losses among the treatments at P1 (table 6). The hydromulch treatments generally had lower concentrations and losses compared to straw and to a lesser degree straw + PAM, particularly the FGM mulch. This is more likely directly related to the amount of erosion that was occurring with the low straw application rate. In general, nutrient losses were much lower on P2 than on P1 and P3. On P3, nutrient losses were recorded only during the first three storm events since runoff volumes for storm $4(33 \mathrm{~mm})$ and $5(64 \mathrm{~mm})$ were unknown due to damage to the plot barriers during the fourth event resulting in leakage, and during the fifth event all of the collection tubs overflowed. Storms 3 to 5 occurred over a period of five days. On P1, TKN losses were $2.6 \%$ to $12 \%$ of applied $\mathrm{N}$ while losses on P2 were less than 1\% and on P3 losses were around 1\%, except for WCB that lost $2.8 \%$. The amount of $\mathrm{PO}_{4}$ lost on $\mathrm{P} 1$ was $0.6 \%$ to $3.6 \%$ of applied while on P2 it was $<0.15 \%$ and on P3 it was $0.2 \%$ to $0.8 \%$. On P1, the first storm event occurred only three days after setup, possibly "washing" the nutrients off the site along with the high sediment losses compared to P2 and P3. The fertilizer was applied by the contractor, so there was likely some variation in application rates between the sites as well. For comparison, on established turf and much less steep (8\%) slopes, Linde and Watschke (1997) had similar losses but only if the turf was irrigated right after fertilization. Rice and Horgan (2011) had up to $15 \%$ losses on established turf on a $4 \%$ slope using artificial rainfall.

Biomass and Vegetative Cover. On CP, there were no differences for aboveground biomass; however, vegetative cover was higher for straw and straw + PAM compared to BFM, WFM, and WCB (table 7). On M,

Table 7

Average aboveground biomass and cover percentage at all five sites in the Coastal Plain (CP), Mountain $(M)$, and Piedmont ( $P_{1}$ through $P_{3}$ ) regions. Treatment means within each site with different letters are significantly different at $\alpha=0.05$.

\begin{tabular}{|c|c|c|c|c|c|}
\hline Treatment & $\mathbf{C P}$ & $\mathbf{M}$ & P1 & $\mathbf{P 2}$ & P3 \\
\hline Straw & 315 & 445 & $1,315 a$ & $540 a$ & 1,334ab \\
\hline Straw + PAM & 241 & 500 & $1,124 a b$ & $364 a b$ & $1,130 b$ \\
\hline SMM & $\mathrm{N} / \mathrm{A}$ & 382 & 1,039ab & $\mathrm{N} / \mathrm{A}$ & 2,174ab \\
\hline BFM & 226 & 398 & 1,149ab & $\mathrm{N} / \mathrm{A}$ & $\mathrm{N} / \mathrm{A}$ \\
\hline FGM & N/A & 335 & $931 b$ & $150.1 \mathrm{c}$ & $\mathrm{N} / \mathrm{A}$ \\
\hline WFM & 310 & $\mathrm{~N} / \mathrm{A}$ & $\mathrm{N} / \mathrm{A}$ & $280 a b$ & $2,305 a$ \\
\hline WCB & 322 & $\mathrm{~N} / \mathrm{A}$ & $\mathrm{N} / \mathrm{A}$ & $194 \mathrm{bc}$ & $2,506 a$ \\
\hline Straw & $68 a$ & 50 & 72 & $56 a$ & $75 b$ \\
\hline Straw + PAM & $66 a$ & 57 & 68 & $54.7 a$ & $67 b$ \\
\hline SMM & $\mathrm{N} / \mathrm{A}$ & 39 & 65 & $\mathrm{~N} / \mathrm{A}$ & $93 a$ \\
\hline BFM & $53 b$ & 41 & 71 & $\mathrm{~N} / \mathrm{A}$ & $\mathrm{N} / \mathrm{A}$ \\
\hline FGM & $\mathrm{N} / \mathrm{A}$ & 41 & 69 & $28.4 b$ & $\mathrm{~N} / \mathrm{A}$ \\
\hline WFM & $55 b$ & $\mathrm{~N} / \mathrm{A}$ & $\mathrm{N} / \mathrm{A}$ & $34.4 b$ & $94 a$ \\
\hline WCB & $56 b$ & $\mathrm{~N} / \mathrm{A}$ & $\mathrm{N} / \mathrm{A}$ & $32 b$ & $96 a$ \\
\hline
\end{tabular}

Notes: $\mathrm{PAM}=$ polyacrylamide. $\mathrm{FGM}=$ flexible growth media. $\mathrm{SMM}=$ stabilized mulch matrix. $\mathrm{BFM}$ $=$ bonded fiber matrix. WFM $=$ wood fiber mulch. WCB $=70: 30$ wood fiber/cellulose blend. N/A = not assessed at that site.

there were no differences for aboveground biomass or vegetative cover across treatments. Generally on this site, aboveground biomass (from 313 to $454 \mathrm{~kg} \mathrm{ha}^{-1}$ [280 to 405 $\left.\mathrm{lb} \mathrm{ac} \mathrm{ac}^{-1}\right]$ ) and vegetative cover (32\% to $56 \%$ ) were relatively low. Average mean temperatures for September to October based on State Climate Office of North Carolina for the area around West Jefferson were around $14^{\circ} \mathrm{C}\left(57.2^{\circ} \mathrm{F}\right)$. Optimum air temperature for tall fescue (Festuca arundinacea) germination is $20^{\circ} \mathrm{C}$ to $30^{\circ} \mathrm{C}\left(68^{\circ} \mathrm{F}\right.$ to $\left.86^{\circ} \mathrm{F}\right)$, so grass growth was likely inhibited. There was also relatively light rainfall at this site during the experiment (table 1), which likely slowed establishment.

Overall grass establishment was good on P1 with aboveground biomass and percentage cover between 875 to $1,038 \mathrm{~kg} \mathrm{ha}^{-1}$ (781 to $926 \mathrm{lb} \mathrm{ac}^{-1}$ ) and $59 \%$ to $72 \%$, respectively. However, on P2 overall grass establishment was much poorer with aboveground biomass of 137 to $472 \mathrm{~kg} \mathrm{ha}^{-1}$ (122 to $420 \mathrm{lb}$ $\mathrm{ac}^{-1}$ ) and cover of $32 \%$ to $56 \%$, with weed species dominating. This is likely due to the time of year, with P1 seeded in May and P2 in November, as discussed below. On P1 and P2, the contractor applied straw, seed, fertilizer, and lime on the whole slope area one day before setup. We raked the straw from the plots that were to be covered with hydromulch and added back tall fescue at 56 $\mathrm{kg} \mathrm{ha}^{-1}\left(50 \mathrm{lb} \mathrm{ac}^{-1}\right)$ in case the raking process removed the applied seed. While we expected this might produce more grass on hydromulch plots at $\mathrm{P} 1$ and $\mathrm{P} 2$, on both sites FGM cover produced less aboveground biomass compared to straw. This was unexpected since FGM ground cover reduced runoff volumes, turbidity, TSS, and TSE compared to the straw cover. It is possible that recommended application rate of $3,900 \mathrm{~kg} \mathrm{ha}^{-1}$ $\left(3,500 \mathrm{lb} \mathrm{ac}^{-1}\right.$; table 3$)$ for hydromulch for 2:1 slopes is too high, forming an effective ground cover for erosion control but inhibiting grass establishment. The WFM at a lower rate $\left(2,240 \mathrm{~kg} \mathrm{ha}^{-1}\left[2,000 \mathrm{lb} \mathrm{ac}^{-1}\right]\right.$; table 3$)$ had significantly greater grass biomass on P2 with no differences in erosion or water quality. Several other studies found that BFM had less ground cover and biomass compared to straw (Benik et al. 2003b; Babcock 2008; McLaughlin and Brown 2006). Greenhouse tests in soil trays with seed and mulch applied performed as part of this project suggested that fescue growth may be inhibited by some hydromulches, either physically or through more rapid moisture loss (Lee 2012).

Site P3 in general had a good grass establishment (67\% to $96 \%$ cover), and weeds were the dominant vegetation on the straw and straw + PAM plots, probably as a result of seeds from the straw. The hydromulches generally produced more grass on $\mathrm{P} 3$, probably due to excessive tackifier application on the straw and straw + PAM plots. The rest of the slope that was not in our plots had straw ground cover with tackifier applied the same day as the plots. In areas where less tackifier 
was applied, grass cover was clearly better than on the straw and straw + PAM test plots, and other nearby areas with high tackifier applications also had reduced grass cover. At P1 and P3, where we had a good grass establishment, there were no differences in runoff water quality between treatments at the end of the sampling period. On P2, where grass establishment was poor, differences were apparent even three months after setup.

The poor grass establishment at $\mathrm{M}$ and $\mathrm{P} 2$ (42\% and $41 \%$ average cover, respectively) may be related to testing during the cooler season (September to November of 2010 and November of 2011 to February of 2012). In addition, both sites had low rainfall amounts with poor distribution, with only about 50 $\mathrm{mm}$ ( 2 in) in the month after seeding. $M$ had $60 \%$ of normal rainfall, while on $\mathrm{P} 2$ rainfall occurred 10 days after seeding and it was another 10 days before the second rain event. At P1, there was light rainfall the day after seeding and rainfall (25 $\mathrm{mm}$ [1 in]) 2 days later, with only 3 more days until another rain event. Similar to P1, P3 had light rainfall 1 day after seeding, and the first rainfall ( $2.5 \mathrm{~mm}$ [0.1 in]) 12 days later did not produce runoff. Three days after there was 22.9 $\mathrm{mm}$ (0.9 in) of rain, followed by another rain event 3 days later. Our findings are similar to the results cited by Babcock and McLaughlin (2011), suggesting that weather factors are more important than ground cover treatment factors in successfully establishing vegetation. They linked rainfall deficits to poor grass growth and found that delayed rainfall after planting also resulted in low biomass over time. Also, Bochet and GarcíaFayos (2004) found that road fills are better for plant establishment than road cuts due to lower fertility and moisture holding capacity in cut soils. Sites CP, P1, and P3 were fill slopes and had stronger grass stands than sites $\mathrm{M}$ and P2, which were cut slopes.

This suggests that when moisture is limited due to rainfall patterns, it may be economical to irrigate newly seeded areas when temperatures allow for growth. In many newly developed areas there may not be a municipal water supply at the site, but a water truck could be used to apply a light irrigation during dry periods. A $10,000 \mathrm{~L}$ (4,000 gal) water truck could apply approximately $4 \mathrm{~mm}$ (0.15 in) of irrigation to a 0.4 ha $(1 \mathrm{ac})$ newly seeded area and presumably water at least 2.3 ha $(5 \mathrm{ac})$ in a day. Local (Raleigh, North Carolina) rental costs would be US $\$ 600 \mathrm{~d}^{-1}$, plus labor of approximately US $\$ 100 \mathrm{~d}^{-1}$, for a total of US $\$ 700 \mathrm{~d}^{-1}$ or US $\$ 304 \mathrm{ha}^{-1} \mathrm{~d}^{-1}$ (US\$140 $\mathrm{ac}^{-1} \mathrm{~d}^{-1}$ ). If the equipment is already on site, as it often is for dust control in our region, the costs would be much less. Compared to the recent North Carolina Department of Transportation bid costs of approximately US $\$ 4,400 \mathrm{ha}^{-1}$ (US\$2,000 $\mathrm{ac}^{-1}$ ) for applying seed, fertilizer, lime, straw, and tackifier, the cost to keep the grass alive and growing might be economically feasible and help to minimize erosion.

It might be expected that PAM would improve vegetation establishment since it has been shown to increase infiltration, reduce surface hardness, and preserve soil structure (Sojka et al. 2007; Green et al. 2000; Yu et al. 2003; Flanagan et al. 2002a, 2002b). Some studies found that PAM did improve vegetation establishment (McLaughlin and Brown 2006; Flanagan et al. 2002b). In our study, PAM did not have any effects on grass establishment at any study site. Since PAM did not reduce runoff volume and reduced turbidity only at one site, effects on grass growth would not be expected.

\section{Summary and Conclusions}

This study was conducted to evaluate several impacts of hydromulches and straw + PAM on runoff water quality and vegetative establishment compared to straw on steep slopes. The study was conducted on five sites around North Carolina. There were large differences in the results between sites due to site-specific conditions and weather.

On two out of five sites, no differences between treatments were found most likely due to sandy textured soils that allowed high infiltration and relatively light rainfall events on one of the sites. On the remaining three sites, we had different results. On the site where straw cover was lower (about 75\% coverage), there was a general trend of hydromulches having lower runoff volumes and turbidity compared to the straw, whereas on sites that had higher straw cover (>95\%), the trend was for hydromulches to have greater runoff volumes, turbidity, TSS, and TSE compared to straw. We also found that more economical hydromulches (WFM and WCB) were less effective in erosion control than straw and SMM on 2:1 slopes. The addition of PAM to straw resulted in lower average turbidity across all storm events on only one site. However, even though PAM was not beneficial on other sites when data were aver- aged across all storm events, improvements in runoff water quality were sometimes evident during first few storm events. Nutrient losses were relatively minor compared to the prescribed application rate. Grass establishment was the same or better under straw compared to the hydromulches on all but one site, at which an over-application of asphalt tackifier to the straw inhibited grass growth. The addition of PAM did not improve grass establishment compared to straw alone at any site. Overall, we found that straw, when applied at a rate that sufficiently covers the soil, usually prevents erosion and nutrient losses and establishes grass as well as or better than hydromulches under a wide variety of conditions.

\section{References}

Akbarzadeh,A., R.T. Mehrjardi, H.G. Refahi, H. Rouhipour and M. Gorji. 2009. Application of soil conditioners and man-made erosion control materials to reduce erosion risk on sloping lands. African Journal of Plant Science Volume 3(4):74-84.

Babcock, D.L. 2008. Performance of mulches and polyacrylamide for erosion control and vegetative establishment. Master of Science thesis, North Carolina State University.

Babcock, D.L., and R.A. McLaughlin. 2011. Runoff water quality and vegetative establishment for groundcovers on steep slopes. Journal of Soil and Water Conservation 66(2):132-141, doi:10.2489/jswc.66.2.132.

Babcock, D.L., and R.A. McLaughlin. 2013. Erosion control effectiveness of straw, hydromulch, and polyacrylamide in a rainfall simulator. Journal of Soil and Water Conservation 68(3):219-225, doi:10.2489/ jswc.68.3.221.

Benik, S.R., B.N. Wilson, D.D. Biesboer, B. Hansen, and D. Stenlund. 2003a. Evaluation of erosion control products using natural rainfall events. Journal of Soil and Water Conservation 58(2):98-105.

Benik, S.R., B.N. Wilson, D.D. Biesboer, B. Hansen, and D. Stenlund. 2003b. Performance of erosion control products on a highway embankment. Transactions of the American Society of Agricultural Engineers 46(4):1113-1119.

Bochet, E., and P. García-Fayos. 2004. Factors controlling vegetation establishment and water erosion on motorway slopes in Valencia, Spain. Restoration Ecology 12(2):166-174.

Clesceri, L.S., A.E. Greenberg, and A.D. Eaton. 1998. Standard Methods for the Examination of Water and Wastewater, 20th edition, 257-258. Washington, DC: American Public Health Association, American Water Works Association, and Water Environment Federation. 
Dane, J.H., G.C. Topp, and L.K. Al-Amoodi. 2004. Methods of Soil Analysis: Physical Methods. Madison, WI: Soil Science Society of America.

Flanagan, D.C., K. Chaudhari, and L.D. Norton. 2002a. Polyacrylamide soil amendment effects on runoff and sediment yield on steep slopes: Part I. Simulated rainfall conditions. Transactions of the American Society of Agricultural Engineers 45(5):1327-1337.

Flanagan, D.C., K. Chaudhari, and L.D. Norton. 2002b. Polyacrylamide soil amendment effects on runoff and sediment yield on steep slopes: Part II. Natural rainfall conditions. Transactions of the American Society of Agricultural Engineers 45(5):1339-1351.

Gee, G.W., and D. Or. 2002. Particle size analysis. In Methods of Soil Analysis Part 4, Physical Methods, ed. J.H. Dane and G.C. Topp, 255-293. Madison, WI: Soil Science Society of America.

Green, V.S., D.E. Stott, L.D. Norton, and J.G. Graveel. 2000. Polyacrylamide molecular weight and charge effects on infiltration under simulated rainfall. Soil Science Society of America Journal 64(5):1786-1791.

Greenberg, A.E., S.C. Leonore, and A.D. Eaton. 2005. Standard Methods for the Examination of Water and Wastewater, 21st edition. Washington, DC: American Public Health Association, American Water Works Association, and Water Environment Federation.

Hayes, S.A., R.A. McLaughlin, and D.L. Osmond. 2005. Polyacrylamide use for erosion and turbidity control on construction sites. Journal of Soil and Water Conservation 60(4):193-199.

Holt, G., M. Buser, D. Harmel, K. Potter, and M. Pelletier. 2005. Comparison of cotton-based hydro-mulches and conventional wood and paper hydro-mulches: Study 1. The Journal of Cotton Science 9:121-127.

Lee, G. 2012. Comparison of five hydromulches and polyacrylamide to straw for erosion control and vegetation establishment on steep slopes. Master's thesis, North Carolina State University Department of Soil Science. http://catalog.lib.ncsu.edu/record/ NCSU2713517.

Lee, S.S., C.J. Gantzer, A.L. Thompson, and S.H. Anderson. 2010. Polyacrylamide and gypsum amendments for erosion and runoff control on two soil series. Journal of Soil and Water Conservation 65(4):233-242, doi:10.2489/jswc.65.4.233.

Lemly, A.D. 1982. Erosion control at construction sites on red clay soils. Environmental Management 6(4):343-352.

Linde, D.T., and T.L. Watschke. 1997. Nutrients and sediment in runoff from creeping bentgrass and perennial ryegrass turfs. Journal of Environmental Quality 26:1248-1254.

Mannering, J.V., and L.D. Meyer. 1963. The effect of various rates of surface mulch on infiltration and erosion. Soil Science Society of America Journal 27:84-86.

McLaughlin, R.A., and T.T. Brown. 2006. Evaluation of erosion control products with and without added polyacrylamide. Journal of the American Water Resources Association 42(3):675-684.
Mostaghimi, S., T.M. Gidley, T.A. Dillaha, and R.A. Cooke. 1994. Effectiveness of different approaches for controlling sediment and nutrient losses from eroded land. Journal of Soil and Water Conservation 49(6):615-620.

Partington, M., and G. Mehuys. 2005. Effectiveness of polyacrylamide in reducing soil erosion on steep slopes. Paper No. 052052. Paper presented at the American Society of Agricultural and Biological Engineers Annual Meeting. Tampa, FL, July 17-20, 2005.

Peterson, J.R., D.C. Flanagan, and J.K. Tishmack. 2002. PAM application method and electrolyte source effects on plot-scale runoff and erosion. Transactions of the American Society of Agricultural Engineers 45(6):1859-1867.

Rice, P.J., and B.P. Horgan. 2011. Nutrient loss with runoff from fairway turf: An evaluation of core cultivation practices and their environmental impact. Environmental Toxicology and Chemistry 30(11):2473-2480.

Roa-Espinosa, A., G.D. Bubenzer, and E.S. Miyashita. 1999. Sediment and runoff control on construction sites using four application methods of polyacrylamide mix. Paper presented at the American Society of Agricultural Engineers/Canadian Society of Agricultural EngineersSCGR Annual International Meeting, Toronto, Ontario, Canada, July 18-21, 1999.

SCONC (State Climate Office of North Carolina). 2017. 1971-2000 Climate Normals. Raleigh, NC: State Climate Office of North Carolina. http://sco-web1. meas.ncsu.edu/cronos/normals.php.

Sojka, R.E., D.L. Bjorneberg, J.A. Entry, R.D. Lentz, and W.J. Orts. 2007. Polyacrylamide in agriculture and environmental land management. Advances in Agronomy 92:75-162.

Soupir, M.L., S. Mostaghimi, A. Masters, K.A. Flahive, D.H. Vaughan, A. Mendez, and P.W. McClellan. 2004. Effectiveness of polyacrylamide (PAM) in improving runoff water quality from construction sites. Journal of the American Water Resources Association 40(1):53-66. USEPA (US Environmental Protection Agency). 2005. Stormwater Phase II Final Rule. EPA 833-F-00-008. Washington, DC: US Environmental Protection Agency. https://www3.epa.gov/npdes/pubs/fact2-6.pdf.

USEPA. 2012a. Watershed Assessment, Tracking, and Environmental Results: National Summary of State Information. Washington, DC; US Environmental Protection Agency. http://ofmpub.epa.gov/waters10/ attains_nation_cy.control.

USEPA. 2012b. Construction General Permit (CGP) National Pollutant Discharge Elimination System General Permit for Discharges from Construction Activities. Washington, DC: US Environmental Protection Agency. http://www.epa.gov/npdes/pubs/ cgp2012_finalpermit.pdf.

USEPA. 2016. National Rivers and Streams Assessment. Washington, DC: US Environmental Protection Agency. https://www.epa.gov/national-aquatic-resourcesurveys/nrsa.
Vacher, C.A., R.J. Loch, and S.R. Raine. 2003. Effect of polyacrylamide additions on infiltration and erosion of disturbed lands. Australian Journal of Soil Research 41:1509-1520.

Whitley, K.D. 2011. Evaluation of polyacrylamide for improvement in soil infiltration and field evaluation of hydromulches for water quality and vegetation establishment. Master's thesis, North Carolina State University Department of Soil Science.

Yu, J.T., L.I. Shainberg, A.I. Mamedov, and G.J. Levy. 2003. Infiltration and erosion in soils treated with dry pam and gypsum. Soil Science Society of America Journal 67(2):630-636. 